Check for updates

Cite this: Mater. Adv., 2020,

1,625

\section{Lithium-ion battery performance enhanced by the combination of Si thin flake anodes and binary ionic liquid systems $\dagger$}

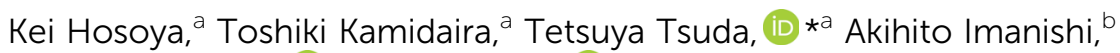 \\ Masakazu Haruta, (ID c Takayuki Doi, (iD ' Minoru Inaba ${ }^{c}$ and Susumu Kuwabata*a
}

\begin{abstract}
The use of ionic liquid (IL)-based electrolytes is one of the methods for solving various problems that pertain to large-capacity anodes, such as Si and Li, for next-generation lithium ion batteries (LIBS). There is insufficient information about the combination of such anodes and IL electrolytes. In the present study, a Si thin flake, which is one of the promising $\mathrm{Si}$ anode active materials, and binary IL electrolytes, 83.3-16.7 mol\% 1-ethyl-3methylimidazolium (bis((fluorosulfonyl)amide)) ([ $\mathrm{C}_{2}$ mim][FSA])-lithium bis(trifluoromethanesulfonyl)amide (Li[TFSA]),

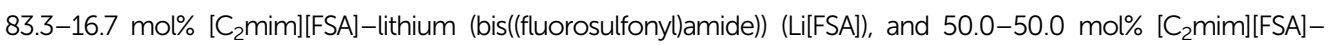
$\mathrm{Li}[\mathrm{FSA}]$, were used for collecting various information on the battery performance, morphology variation of the $\mathrm{Si}$ thin flake, and chemical species in the solid electrolyte interface (SEI) layer. Operando scanning electron microscopy (SEM) and ex situ X-ray photoelectron spectroscopy (XPS) revealed that the SEl layer composition depends on the Li salt species and that their molar fractions in the binary IL electrolytes strongly affect the morphology variation in the Si thin flakes during the charge process. When the favorable Li conductive components, e.g., LiF and $\mathrm{Li}_{3} \mathrm{~N}$, were abundantly contained in the SEI layer, the charge and discharge behavior of the Si thin flake anode was greatly improved. The best battery performance was obtained by the combination of the Si thin flake composite anode and the 50.0-50.0 mol\% [C ${ }_{2}$ mim] [FSA]-Li[FSA]. Discharge capacity above $1100 \mathrm{~mA} \mathrm{~h} \mathrm{~g}^{-1}$ was achieved even after 500 cycles under the charge and discharge conditions at a $3 \mathrm{C}$ rate.
\end{abstract}

Received 11th May 2020

Accepted 5th June 2020

DOI: $10.1039 / \mathrm{d} 0 \mathrm{ma} 00296 \mathrm{~h}$

rsc.li/materials-advances

\section{Introduction}

A secondary battery with high capacity and favorable rate capability that exceeds the current Li-ion battery (LIB), which consists of a graphite anode and a lithium-transition metal oxide cathode, is expected to be the future energy storage device supporting smart grid communities, electric vehicles, and Internet of Things (IoT) technology. ${ }^{1,2}$ One such battery is the Si anode type LIB as Si has a very high theoretical capacity $\left(3579 \mathrm{~mA} \mathrm{~h} \mathrm{~g}^{-1}\right)$, which is comparable to that of the Li metal anode $\left(3860 \mathrm{~mA} \mathrm{~h} \mathrm{~g}^{-1}\right)$. However, during the charge-discharge processes, the $\mathrm{Si}$ anode suffers from a dramatic volume change that often causes Si pulverization accompanied by the conductive path loss, resulting in the rapid fading of battery

\footnotetext{
${ }^{a}$ Department of Applied Chemistry, Graduate School of Engineering, Osaka University, 2-1 Yamada-oka, Suita, Osaka 565-0871, Japan. E-mail: kuwabata@chem.eng.osaka-u.ac.jp, ttsuda@chem.eng.osaka-u.ac.jp

${ }^{b}$ Department of Chemistry, Graduate School of Engineering Science, Osaka University, 1-3 Machikaneyama, Toyonaka, Osaka 560-8531, Japan ${ }^{c}$ Department of Molecular Chemistry and Biochemistry, Doshisha University, 1-3 Tatara Miyakodani, Kyotanabe, Kyoto 610-0321, Japan

$\dagger$ Electronic supplementary information (ESI) available: Additional data (Fig. S1, Tables S1-S3, and Movies S1 and S2) and captions for Movies. See DOI: 10.1039/ d0ma00296h
}

capacity. Several approaches for overcoming this issue have already been proposed. Nanoscale morphology designs of Si materials, such as nanowires ${ }^{3,4}$ nanotubes, ${ }^{5}$ thin films, ${ }^{6}$ and thin flakes, ${ }^{7,8}$ are highly effective. Recently, it was revealed by in situ and operando scanning electron microscopy (SEM) ${ }^{9}$ that the addition of flexibility to the Si material by nanoscale material tailoring is an important factor for suppressing the degradation. Another approach for improving capacity fading is to use organic additives, such as 4-fluoroethylene carbonate (FEC) and vinylene carbonate (VC), as a component of the battery electrolyte. For example, the capacity retention rate was improved from $17 \%$ without an additive to $60 \%$ with FEC and $74 \%$ with VC due to the variation in chemical species and their compositions in the solid electrolyte interface (SEI), which form a physicochemically stable and good Li-ion conducting SEI layer on the Si anode. ${ }^{10}$

Ionic liquids (ILs), which are liquid salts at room temperature, have great potential as advanced electrolytes for LIBs because of their various unique properties including wide electrochemical window, negligible vapor pressures, nonflammability, and good thermal stability. ${ }^{11,12}$ In particular, bis((fluorosulfonyl)amide) anion $\left([\mathrm{FSA}]^{-}\right)$-based IL electrolytes have been widely used for Si anode LIBs, as [FSA $]^{-}$contributes to the formation of a favorable SEI layer onto the Si anode. ${ }^{13-16}$ However, there is insufficient information on 
the effect of the $\mathrm{Li}(\mathrm{I})$ and $[\mathrm{FSA}]^{-}$concentration in the IL electrolyte on the battery performance although it is known that the aqueous and organic battery electrolytes become more favorable at higher Li salt concentrations (in many cases, up to $50 \mathrm{~mol} \%$ ). ${ }^{17-21}$

In the present study, in order to improve the cycle characteristics and high-rate charge-discharge performance of the Si anode LIBs, the effects of the Li salt species, Li[FSA], and lithium bis((trifluorosulfonyl)amide) (Li[TFSA]), and their molar fraction in the binary electrolytes of 1-ethyl-3-methylimidazolium (bis((fluorosulfonyl)amide)) ([ $\left.\left.\mathrm{C}_{2} \mathrm{mim}\right][\mathrm{FSA}]\right)-\mathrm{Li}[\mathrm{FSA}]$ and $\left[\mathrm{C}_{2} \mathrm{mim}\right][\mathrm{FSA}]-$ $\mathrm{Li}[\mathrm{TFSA}]$ on the Si thin flake composite anode are examined by evaluating the battery performance and analyzing the battery reactions through operando $\mathrm{SEM}^{9,22}$ and ex situ X-ray photoelectron spectroscopy (XPS). The combination of the Si anode and IL electrolyte is proposed for designing a high-performance $\mathrm{Si}$ anode LIB that has the potential to be the future of energy storage devices.

\section{Experimental}

\section{Preparation and evaluation of Si composite anode LIBS}

A Si thin flake (Si-LeafPowder ${ }^{\circledR}$, OIKE \& Co., Ltd (Japan)), with vertical and horizontal sizes of 3-5 $\mu \mathrm{m}$ (Fig. 1a) and a thickness of $100 \mathrm{~nm}$ (Fig. 1b), was used as an active anode material. A composite electrode containing an $83.3 \mathrm{wt} \%$ Si thin flake, a $5.6 \mathrm{wt} \%$ conductive additive (Ketjen Black (KB), EC600JD, Lion Corp. (Japan)), and a $11.1 \mathrm{wt} \%$ water soluble binder (carboxymethyl cellulose sodium salt (NaCMC), Nacalai Tesque (Japan)) was prepared by the procedure used in a previous study. ${ }^{7}$ The mass loading of the Si-LPs on the current collector was $0.4-0.5 \mathrm{mg} \mathrm{cm}^{-2}$. CR2032type coin full cells were constructed by stacking the Si composite anode, a polyolefin separator (Nippon Sheet Glass Co., Ltd (Japan)), and a $\mathrm{LiCoO}_{2}$ composite cathode with an $\mathrm{Al}$ foil current collector (3.0 $\mathrm{mA} \mathrm{h} \mathrm{cm} \mathrm{cm}^{-2}$, Hohsen (Japan)) in an Ar-filled glove box (OmniLab, Vacuum Atmospheres Co. (USA), $\mathrm{O}_{2}$ and $\mathrm{H}_{2} \mathrm{O}<1 \mathrm{ppm}$ ). The quantitative ratio between the cathode and the anode materials was set so that the actual capacity of the $\mathrm{LiCoO}_{2}$ electrode was more than twice the theoretical capacity of the $\mathrm{Si}$ composite electrode. The electrolytes used were binary IL systems: 83.3-16.7 mol\% $\left[\mathrm{C}_{2} \mathrm{mim}\right][\mathrm{FSA}]-\mathrm{Li}[\mathrm{TFSA}] ;$ 83.3-16.7 $\mathrm{mol} \%$ [ $\left.\mathrm{C}_{2} \mathrm{mim}\right][\mathrm{FSA}]-\mathrm{Li}[\mathrm{FSA}]$; and 50.0-50.0 $\mathrm{mol} \%\left[\mathrm{C}_{2} \mathrm{mim}\right][\mathrm{FSA}]-\mathrm{Li}[\mathrm{FSA}]$. These electrolytes were prepared by adding a given amount of Li[TFSA] (Morita Chemical Industries Co., Ltd (Japan)) or Li[FSA] (Nippon Shokubai Co., Ltd (Japan)) to [ $\left.\mathrm{C}_{2} \mathrm{mim}\right][\mathrm{FSA}]$ (Kanto Chemical Co., Inc. (Japan)) in an Ar-filled glove box. The charge-discharge tests were conducted at $298 \mathrm{~K}$ in a constant current/constant voltage $(\mathrm{CC} / \mathrm{CV})$ mode between -3.88 and $-2.40 \mathrm{~V}\left(v s\right.$. $\left.\mathrm{LiCoO}_{2}\right)$ using a battery test system (HJ1001SD8, Hokuto Denko (Japan)). The cut-off current for the CV mode was $1 / 10$, the same as that for the CC mode. Unless otherwise noted, the discharge capacity per Si weight is represented as $\mathrm{mA} \mathrm{h} \mathrm{g}{ }^{-1}$ in this paper.

\section{Characterization of the SEI layer formed on Si anodes}

A SEI layer formed on Si anodes was characterized by an XPS system (AXIS Ultra DLD, Kratos (UK)). Ex situ XPS analyses were
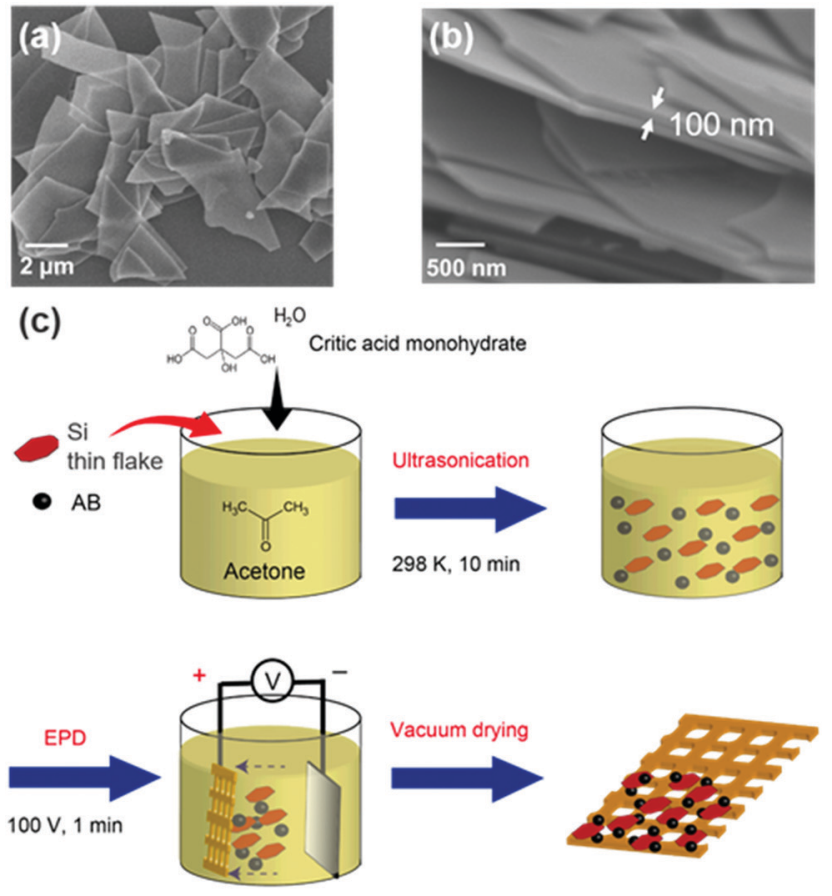

(d)

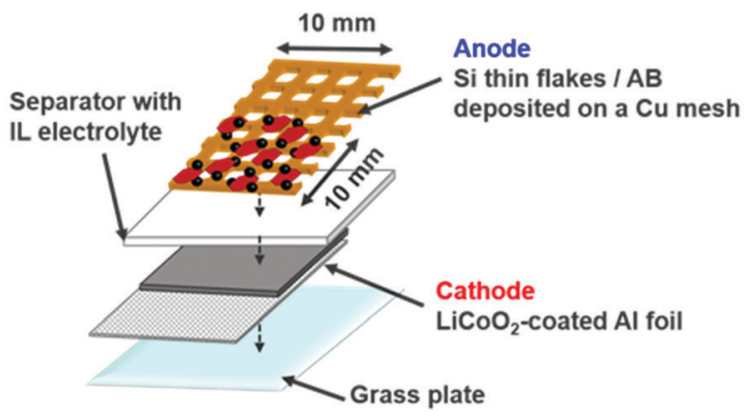

Fig. 1 SEM images of (a) top view and (b) cross-sectional view of the Si thin flakes. Schematic drawings of (c) a binder-free Si anode preparation process and (d) an operando SEM observation cell for the binder-free $\mathrm{Si}$ anode reaction.

conducted using the Si thin flake composite anodes after five charge-discharge processes. The process was performed in CC mode of $1 / 2 \mathrm{C}$ in the coin-type full cell described above. The resultant $\mathrm{Si}$ anodes were rinsed with a battery-grade diethyl carbonate (DEC, Wako (Japan)) in an Ar-filled glove box. XPS measurements were carried out using an airtight transfer vessel to prevent contamination from moisture and oxygen in air.

\section{Preparation of Si anodes for operando SEM observations}

A binder-free Si thin flake anode with a conductive additive (acetylene black (AB), Strem Chemicals (USA)) was prepared using an electrophoretic deposition (EPD) method, as depicted in Fig. $1 c^{9,23}$ The solution for the EPD process was a dry acetone solution containing a $1.00 \mathrm{~g} \mathrm{~L}^{-1} \mathrm{Si}$ thin flake, $0.40 \mathrm{~g} \mathrm{~L}^{-1} \mathrm{AB}$, and $1.00 \mathrm{~g} \mathrm{~L}^{-1}$ citric acid monohydrate (Wako (Japan)) which was sonicated for $20 \mathrm{~min}$ prior to use. A Cu mesh (20 mesh, Nilaco Co. (Japan))and a Pt plate were used as the anode and cathode, respectively. A voltage of $100 \mathrm{~V}$ was applied between the electrodes 
that were set $2 \mathrm{~cm}$ apart, for $60 \mathrm{~s}$ to carry out EPD. Si thin flakes and $\mathrm{AB}$ co-deposited $\mathrm{Cu}$ mesh electrodes were dried at $353 \mathrm{~K}$ under a vacuum over 6 hours to strengthen the adhesion of the Si materials.

\section{Operando SEM experiments}

An operando SEM observation of the binder-free Si anodes was performed using a two-electrode type full cell with a mesh-type anode, a $\mathrm{LiCoO}_{2}$ composite cathode with an $\mathrm{Al}$ foil current collector (3.0 $\mathrm{mA} \mathrm{h} \mathrm{cm}^{-2}$, Hohsen (Japan)), and glass microfiber filter separators (GF/A, Whatman (UK)) with IL electrolytes (Fig. 1d). The three types of binary ILs described above were used as the electrolyte. A commonly used SEM observation system (S-3400N, Hitachi (Japan)) was converted into an operando system by equipping a feed-through terminal, which enables electrochemical measurements in the SEM chamber, with an original SEM system. All the operando experiments were conducted in the vacuum chamber of the SEM system. ${ }^{24}$ The variation in morphology in the $\mathrm{Si}$ anode during the charge-discharge processes in $\mathrm{CC} / \mathrm{CV}$ mode was observed by a secondary electron image mode. The charge-discharge rate was $1 / 2 \mathrm{C}$. The cut-off voltages were -3.88 and $-2.40 \mathrm{~V}$ ( vs. $\mathrm{LiCoO}_{2}$ ), and at the cut-off voltages, the cut-off current was maintained until the $1 / 20 \mathrm{C}$ rate was achieved. The electrochemical experimental conditions were controlled with a potentiostat/galvanostat (VersaSTAT 4, Princeton Applied Research (USA)).

\section{Results and discussion}

\section{Performance of Si thin flake composite anode LIBs with different binary IL electrolytes}

The first three cycles of the charge-discharge profiles recorded at the Si thin flake composite anodes in the coin-type cells with (a) 83.3-16.7 mol\% [C $\left.\mathrm{C}_{2} \mathrm{mim}\right][\mathrm{FSA}]-\mathrm{Li}[\mathrm{TFSA}]$, (b) 83.3-16.7 mol\% $\left[\mathrm{C}_{2} \mathrm{mim}\right][\mathrm{FSA}]-\mathrm{Li}[\mathrm{FSA}]$, and (c) 50.0-50.0 $\mathrm{mol} \%$ [ $\left.\mathrm{C}_{2} \mathrm{mim}\right][\mathrm{FSA}]-$ Li[FSA] IL electrolytes are shown in Fig. 2. In each chargedischarge curve, distinct plateaus related to the lithiation/ delithiation reactions for the Si thin flake appeared. The curves slightly varied with the IL electrolyte conditions. Under the same Li salt molar fraction (Fig. $2 \mathrm{a}$ and b), a better discharge capacity was obtained in the 83.3-16.7 $\mathrm{mol} \%$ [ $\left.\mathrm{C}_{2} \mathrm{mim}\right][\mathrm{FSA}]-$ Li[FSA] electrolyte ( $c a .1900 \mathrm{~mA} \mathrm{~h} \mathrm{~g}^{-1}$ at third cycle). Under a higher Li[FSA] molar fraction condition, i.e., 50.0-50.0 mol\% $\left[\mathrm{C}_{2} \mathrm{mim}\right][\mathrm{FSA}]-\mathrm{Li}[\mathrm{FSA}]$, the highest discharge capacity of over $2100 \mathrm{~mA} \mathrm{~h} \mathrm{~g}^{-1}$ was obtained at the third cycle. In fact, similar experiments were also carried out using the 50.0-50.0 mol\% $\left[\mathrm{C}_{2} \mathrm{mim}\right][\mathrm{FSA}]-\mathrm{Li}[\mathrm{TFSA}]$ electrolyte, but a reversible lithiation reaction was not observed due to the unstable SEI layer formed on the Si anode, as reported by Ishikawa et al. ${ }^{13}$ in a previous paper. These results suggest that $[\mathrm{FSA}]^{-}$is deeply involved in the improvement of cell performance. Fig. 3a indicates the cyclability of the Si anode up to 50 cycles in the three promising electrolytes. As expected from Fig. 2, the highest discharge capacity ( $2200 \mathrm{~mA} \mathrm{~h} \mathrm{~g}{ }^{-1}$ at 50th cycle) and coulomb efficiency ( $>99.5 \%$ ) were obtained in the $50.0-50.0 \mathrm{~mol} \%$ [ $\left.\mathrm{C}_{2} \mathrm{mim}\right][\mathrm{FSA}]-$ Li[FSA] electrolyte. The discharge capacity at different current

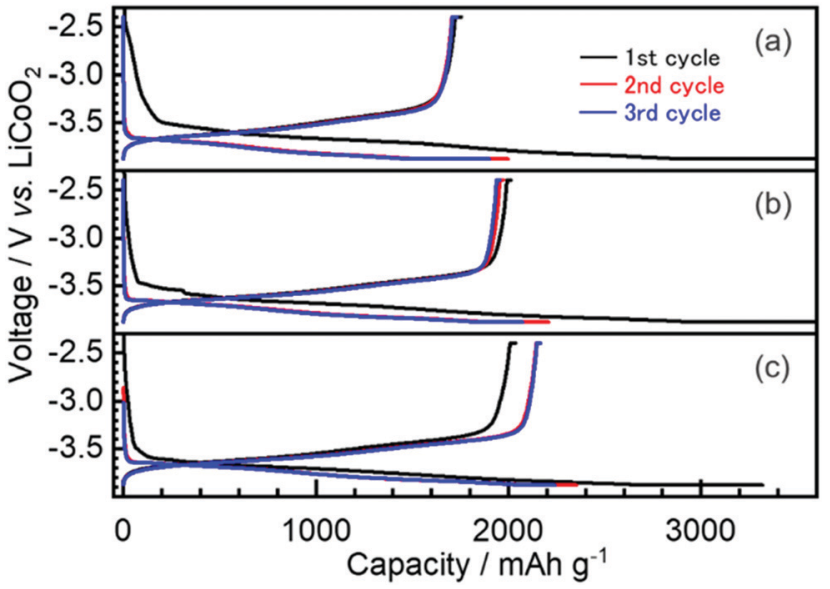

Fig. 2 Charge-discharge curves of the first three cycles for Si thin flake composite anodes in coin-type full cells with different binary IL electrolytes. The charge-discharge processes were carried out in a CC/CV mode. The IL electrolytes were (a) 83.3-16.7 mol\% [C C $_{2}$ mim] [FSA]-Li[TFSA], (b) 83.3-16.7 mol\% [C $\left.\mathrm{C}_{2} \mathrm{mim}\right][\mathrm{FSA}]-\mathrm{Li}[\mathrm{FSA}]$, and (c) 50.0-50.0 mol\% [C $\left.2 \mathrm{mim}\right][\mathrm{FSA}]-$ Li[FSA]. The CC rate was $1 / 6 \mathrm{C}$ and the cut-off voltages were $-3.88 \mathrm{~V}$ and $-2.40 \mathrm{~V}$ (vs. $\mathrm{LiCOO}_{2}$ ). In the $\mathrm{CV}$ mode, the cut-off voltage used for the $\mathrm{CC}$ mode was successively applied until the current value reached 1/60C.

rates is shown in Fig. 3b. The rate characteristics greatly depend on the IL electrolyte species. In the 83.3-16.7 $\mathrm{mol} \%$ [ $\left.\mathrm{C}_{2} \mathrm{mim}\right][\mathrm{FSA}]-$ Li[TFSA] electrolyte, a large capacity drop appeared at 1/3C, whereas most of the capacity was maintained in the two binary IL electrolytes containing $\mathrm{Li}$ [FSA] even at 1C. Surprisingly, in the 50.0-50.0 mol\% $\left[\mathrm{C}_{2} \mathrm{mim}\right][\mathrm{FSA}]-\mathrm{Li}[\mathrm{FSA}]$ electrolyte, outstanding discharge capacities over $2100 \mathrm{~mA} \mathrm{~h} \mathrm{~g}^{-1}$ were obtained at 3C. Such superior high rate charge-discharge behavior was caused by both the high Li(I) carrier density (ca. $3.40 \mathrm{~mol} \mathrm{~L}^{-1}$ at $298 \mathrm{~K}, c f$. , ca. $0.91 \mathrm{~mol} \mathrm{~L}^{-1}$ at $298 \mathrm{~K}$ in 83.3-16.7 $\mathrm{mol} \%$ [ $\left.\mathrm{C}_{2} \mathrm{mim}\right][\mathrm{FSA}]-\mathrm{Li}[\mathrm{FSA}]$. [This value was estimated from Table S1 (ESI $\dagger$ ) and the molecular weight of the ILs as calculated in ref. 25]) and the electrochemically stable SEI layer formation on the anode.

Considering the rate capability shown in Fig. 3b, the binary $\left[\mathrm{C}_{2} \mathrm{mim}\right][\mathrm{FSA}]-\mathrm{Li}[\mathrm{FSA}]$ IL system seems to be the most suitable as the LIB electrolyte. Fig. 4 summarizes the charge-discharge behavior of the Si thin flake composite anodes in the coin-type cell with $83.3-16.7 \mathrm{~mol} \%$ and $50.0-50.0 \mathrm{~mol} \%$ [ $\left.\mathrm{C}_{2} \mathrm{mim}\right][\mathrm{FSA}]-$ $\mathrm{Li}[\mathrm{FSA}] \mathrm{ILs}$ at a $3 \mathrm{C}$ rate. It should be noted that the first five cycles were conducted at $1 / 6 \mathrm{C}$ to form a better SEI layer on the Si anode. Although their discharge capacities differ by $c a$. $500 \mathrm{~mA} \mathrm{~h} \mathrm{~g}{ }^{-1}$, the discharge capacity profile itself is very similar. A higher capacity was attained in the cell with the 50.0-50.0 mol\% IL and a favorable discharge capacity of over $1100 \mathrm{~mA} \mathrm{~h} \mathrm{~g}^{-1}$ was maintained even after 500 cycles. Except the first five cycles conducted at $1 / 6 \mathrm{C}$, the average values of the coulomb efficiency were $99.4 \%$ and $99.7 \%$ for the $83.3-16.7 \mathrm{~mol} \% \mathrm{IL}$ and 50.0-50.0 mol\% IL, respectively. These outstanding performances seem to meet the requirements of the LIB industry.

\section{XPS analysis of SEI layers formed on Si thin flake anodes}

The higher capacity of the Si thin flake composites was achieved in the coin-type full cells with binary $\left[\mathrm{C}_{2} \mathrm{mim}\right][\mathrm{FSA}]-\mathrm{Li}[\mathrm{FSA}] \mathrm{IL}$ 

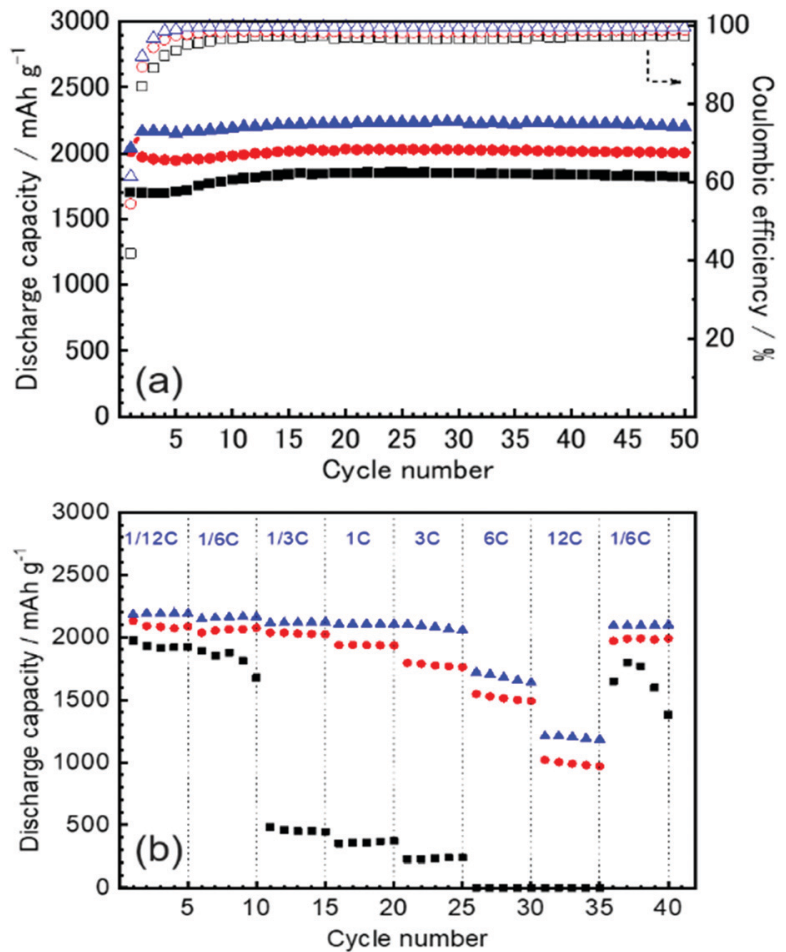

Fig. 3 (a) Results of the cyclability test for the Si thin flake composite anodes in coin-type full cells with different binary IL electrolytes. The test was conducted in the $\mathrm{CC} / \mathrm{CV}$ mode. The $\mathrm{CC}$ rate was $1 / 6 \mathrm{C}$ and the cut-off voltages were $-3.88 \mathrm{~V}$ and $-2.40 \mathrm{~V}$ (vs. $\mathrm{LiCOO}_{2}$ ). In the $\mathrm{CV}$ mode, the cut-off voltage used for the $\mathrm{CC}$ mode was successively applied until the current value reached 1/60C. The electrolytes were $(\boldsymbol{\square}, \square)$ 83.3-16.7 mol\% [C 2 mim][FSA]-Li[TFSA], $(\odot, 0)$ 83.3-16.7 mol\% [C $\left.\mathrm{C}_{2} \mathrm{mim}\right][\mathrm{FSA}]-\mathrm{Li}[\mathrm{FSA}]$, and $(\Delta, \Delta)$ 50.0-50.0 mol\% $\left[\mathrm{C}_{2}\right.$ mim] [FSA]-Li[FSA]. (b) Discharge capacities at different current densities in the $\mathrm{CC} / \mathrm{CV}$ mode. Each discharge process was done five times. The applied current densities were $1 / 12 C, 1 / 6 C, 1 / 3 C, 1 C, 3 C, 6 C$ and $12 C$, and after the $C C$ mode, a rest time was provided at the cut-off voltage until the current density used in the CC mode became one tenth.

electrolytes, in particular, 50.0-50.0 $\mathrm{mol} \%$ [ $\left.\mathrm{C}_{2} \mathrm{mim}\right][\mathrm{FSA}]-\mathrm{Li}[\mathrm{FSA}]$. In order to clarify the reason for this, further information on the SEI layer formed on the Si thin flake anode was collected via ex situ XPS for finding out information on the SEI layer formed on a Si anode. ${ }^{26-28}$ In the IL electrolytes used in the present study, the SEI layer is believed to be generated by the decomposition of FSA and TFSA anions..$^{14,16,29-33}$ Fig. 5 and Fig. S1 (ESI + ) show XPS spectra for Li-1s, F-1s, N-1s, and S-2p on the Si composite anodes taken after five charge-discharge cycles. The electrolytes used were 83.3-16.7 $\mathrm{mol} \%$ [ $\left.\mathrm{C}_{2} \mathrm{mim}\right][\mathrm{FSA}]-\mathrm{Li}[\mathrm{TFSA}]$, 83.3-16.7 $\mathrm{mol} \%$ [ $\left.\mathrm{C}_{2} \mathrm{mim}\right][\mathrm{FSA}]-\mathrm{Li}[\mathrm{FSA}]$, and $50.0-50.0 \mathrm{~mol} \%$ $\left[\mathrm{C}_{2} \mathrm{mim}\right][\mathrm{FSA}]-\mathrm{Li}[\mathrm{FSA}]$. The XPS spectra allowed us to deduce the chemical composition of the SEI layers. F-1s and N-1s spectra show the existence of anions and cations ${ }^{30}$ of each IL but their peak intensity ratio in the $\mathrm{N}-1 \mathrm{~s}$ spectra suggests that their appearance was due to residual ILs at the SEI surface. Li-1s and $\mathrm{F}-1 \mathrm{~s}$ spectra provide $\mathrm{LiF}^{16}$ as a component of the SEI layer. However, the deconvolution of the LiF peak in the F-1s spectrum results in the appearance of two peaks, implying that there are LiF components staying in different chemical environments as previously reported. ${ }^{16}$ Both components are clearly observed for

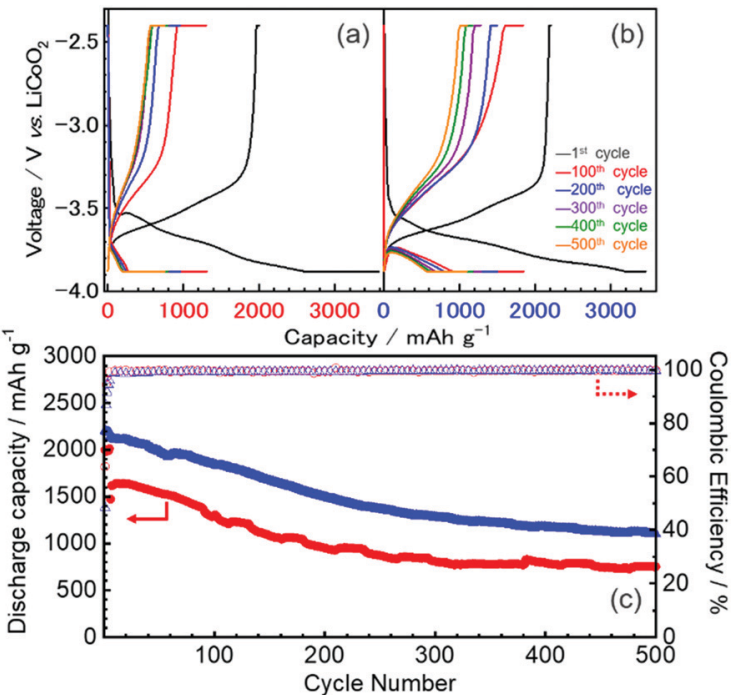

Fig. 4 Results of long-term charge-discharge tests for the Si thin flake composite anodes in coin-type full cells with different IL electrolytes. The test, done in CC/CV mode, was conducted at $3 \mathrm{C}$ after the first five cycles were conducted at $1 / 6 \mathrm{C}$. The cut-off voltages were $-3.88 \mathrm{~V}$ and $-2.40 \mathrm{~V}$ (vs. $\mathrm{LiCOO}_{2}$ ). In the $\mathrm{CV}$ mode, the cut-off voltage used for the $\mathrm{CC}$ mode was successively applied until each current density used in the CC mode became one tenth. Charge-discharge curves of (a) 83.3-16.7 mol\% [ C $_{2}$ mim] [FSA]Li[FSA] and (b) 50.0-50.0 mol\% [ $\left.\mathrm{C}_{2} \mathrm{mim}\right][\mathrm{FSA}]-\mathrm{Li}[\mathrm{FSA}]$ obtained at the 1st, 100th, 200th, 300th, 400th, and 500th cycles. (c) Discharge capacity and coulombic efficiency of the Si composite anode as a function of cycle number. $(0,0)$ 83.3-16.7 mol\% $\left[C_{2}\right.$ mim] $[F S A]-L i[F S A] ;(\Delta, \Delta) \quad 50.0-50.0 \mathrm{~mol} \%$ $\left[\mathrm{C}_{2} \mathrm{mim}\right][\mathrm{FSA}]-\mathrm{Li}[\mathrm{FSA}]$. The open and filled symbols show coulombic efficiency and discharge capacity, respectively.
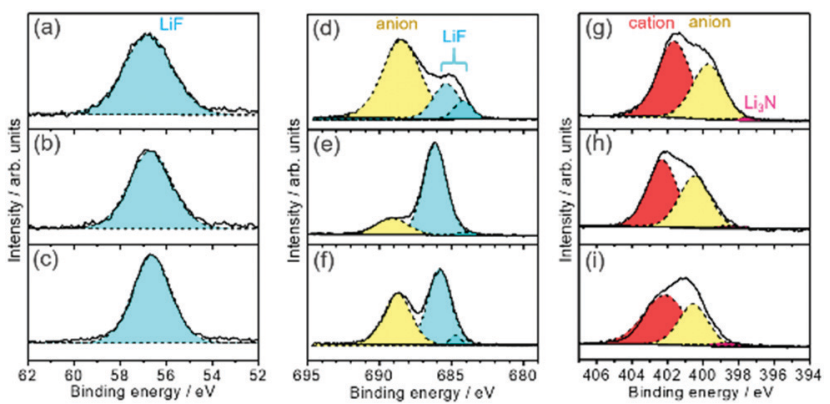

Fig. 5 XPS spectra for $(a-c) L i-1 s,(d-f) F-1 s$, and $(g-i) N-1 s$ of the Si thin flake composite anodes after five charge-discharge cycles. The charge-discharge test was conducted in a CC mode at $1 / 2 \mathrm{C}$, and the cut-off voltages were $-3.88 \mathrm{~V}$ and $-2.40 \mathrm{~V}\left(\mathrm{vs}\right.$. $\left.\mathrm{LiCoO}_{2}\right)$. The IL electrolytes were $(\mathrm{a}, \mathrm{d}$ and $\mathrm{g})$ 83.3-16.7 mol\% [C C $_{2}$ mim] [FSA]-Li[TFSA], (b, e and h) 83.3-16.7 mol\% [C 2 mim][FSA]-Li[FSA], and (c, $f$ and i) 50.0-50.0 mol\% [ $\left.\mathrm{C}_{2} \mathrm{mim}\right][\mathrm{FSA}]-\mathrm{Li}[\mathrm{FSA}]$.

the SEI prepared in IL containing Li[TFSA] but in the SEI layer prepared in the electrolyte containing only $[\mathrm{FSA}]^{-}$the $\mathrm{LiF}$ component with a higher binding energy is dominant. Such differences suggest that the chemical environment around $\mathrm{LiF}$, which makes the binding energy stronger, is more easily created if only $[\mathrm{FSA}]^{-}$is present in the electrolyte. The deconvolution of the $\mathrm{N}-1 \mathrm{~s}$ spectrum provides an ill-defined spectrum assignable to $\mathrm{Li}_{3} \mathrm{~N}(398.1 \mathrm{eV})$, which is known as one of the SEI components having high Li-ion conductivity. ${ }^{30,31}$ The fact that the abundance 
(a)

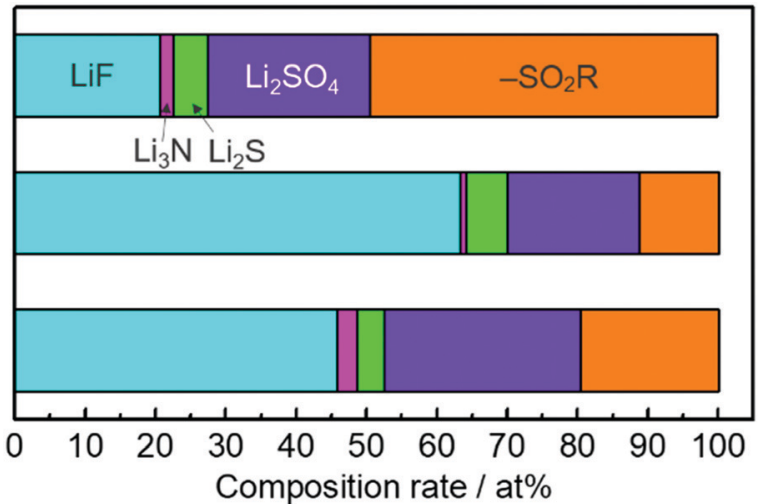

Fig. 6 Chemical species and their composition rates, estimated from XPS data, contained in SEI films formed during the charge process in (a) 83.3$16.7 \mathrm{~mol} \% \quad\left[\mathrm{C}_{2} \mathrm{mim}\right][\mathrm{FSA}]-\mathrm{Li}[\mathrm{TFSA}]$, (b) 83.3-16.7 mol\% [ $\left.\mathrm{C}_{2} \mathrm{mim}\right][\mathrm{FSA}]-$ Li[FSA] and (c) 50.0-50.0 mol\% [ $\left.\mathrm{C}_{2} \mathrm{mim}\right][\mathrm{FSA}]-\mathrm{Li}[\mathrm{FSA}] \mathrm{IL}$ electrolytes.

of $\mathrm{Li}_{3} \mathrm{~N}$ was the highest in the SEI layer prepared in 50.0-50.0 mol\% $\left[\mathrm{C}_{2} \mathrm{mim}\right][\mathrm{FSA}]-\mathrm{Li}[\mathrm{FSA}]$ (see Fig. 6 and Table S2, ESI $\dagger$ ), indicates that such SEI composition is important to get a higher performance out of the full cell with this IL electrolyte, as will be discussed later. Besides, $-\mathrm{SO}_{2} \mathrm{R}(168.9 \mathrm{eV}$ and $170.1 \mathrm{eV}),{ }^{33} \mathrm{Li}_{2} \mathrm{SO}_{4}(167.2$ and $168.1 \mathrm{eV}),{ }^{16,33}$ and $\mathrm{Li}_{2} \mathrm{~S}$ based components $(162.1-165.3 \mathrm{eV}),{ }^{16}$ that have no clear role on battery performance improvement, were also confirmed (Fig. S1, ESI $\dagger$ ).

Fig. 6 shows the relationship between the chemical species and their composition ratios contained in the SEI layers generated in each IL electrolyte. The detailed data are given in Table S2 (ESI $\dagger$ ) and their physical properties are summarized in Table S3 (ESI $\dagger$ ). In 83.3-16.7 $\mathrm{mol} \%$ [ $\left.\mathrm{C}_{2} \mathrm{mim}\right][\mathrm{FSA}]-\mathrm{Li}[\mathrm{TFSA}]$, the composition rate of $\mathrm{Li}$-ion conductive chemical species, i.e., $\mathrm{LiF}$ and $\mathrm{Li}_{3} \mathrm{~N}$, contained in the SEI layer is less than 23 at\%. Meanwhile, when $\left[\mathrm{C}_{2} \mathrm{mim}\right][\mathrm{FSA}]-\mathrm{Li}[\mathrm{FSA}]$ was used, LiF, having favorable $\mathrm{Li}$ ion conductivity and a high shear modulus, became the major component in the SEI layer. At higher Li[FSA] concentration in the IL system, the abundance ratio of $\mathrm{Li}_{3} \mathrm{~N}$, which has both a superior Li ion conductivity and mechanical strength, slightly increased, while that of LiF decreased. Interestingly, the Li ion conductivity for $\mathrm{Li}_{3} \mathrm{~N}$ is more than 150 times higher than that for $\mathrm{LiF}$.

\section{Operando SEM observation of Si thin flake anodes}

Fig. 7 shows the SEM images of the binder-free Si thin flake anode taken in the LIB full cells with the 83.3-16.7 mol\% $\left[\mathrm{C}_{2} \mathrm{mim}\right][\mathrm{FSA}]-\mathrm{Li}[\mathrm{TFSA}]$ and $83.3-16.7 \mathrm{~mol} \% \quad\left[\mathrm{C}_{2} \mathrm{mim}\right][\mathrm{FSA}]-$ $\mathrm{Li}[\mathrm{FSA}] \mathrm{IL}$ electrolytes before and after the 4 th charge process. Here, we also conducted the same experiment in the 50.0-50.0 mol\% $\left[\mathrm{C}_{2} \mathrm{mim}\right][\mathrm{FSA}]-\mathrm{Li}[\mathrm{FSA}] \mathrm{IL}$, however it was difficult to obtain clear SEM images because the SEM image quality of the IL-covered specimen strongly depends on the density of the ILs, i.e., at higher density, the image quality degrades. ${ }^{34}$ As indicated in Table S1 (ESI $\dagger$ ), the 50.0-50.0 mol\% electrolyte has a higher density than the other two electrolytes. Thus, only two results obtained in the 83.3-16.7 mol\% IL electrolytes including the movies by operando SEM observation during the charge process (Movies S1 and S2, ESI $\dagger$ ) are further
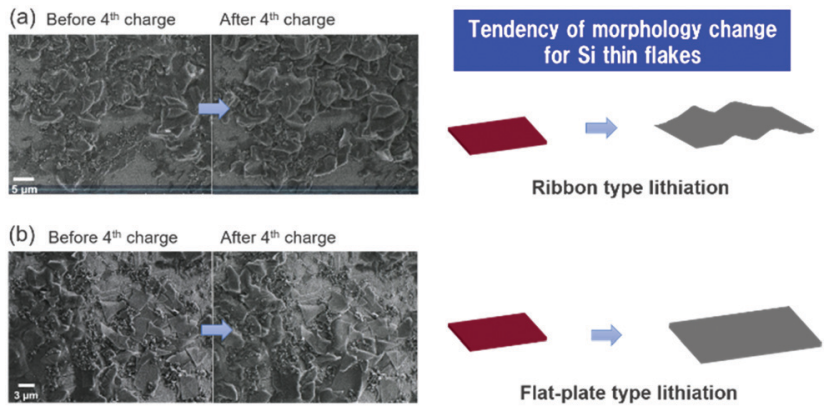

Fig. 7 SEM images of the binder free Si thin flake anode in the operando SEM observation cell before and after the fourth charge process. The test was conducted at a CC/CV mode. The CC rate was $1 / 2 \mathrm{C}$ and the cut-off voltages were $-3.88 \mathrm{~V}$ and $-2.40 \mathrm{~V}\left(\mathrm{vs}\right.$. $\left.\mathrm{LiCoO}_{2}\right)$. The cut-off current density was $1 / 20 \mathrm{C}$. The electrolytes were (a) 83.3-16.7 mol\% [ C $_{2}$ mim] [FSA]-Li[TFSA] and (b) 83.3-16.7 mol\% [C $\left.\mathrm{C}_{2} \mathrm{mim}\right][\mathrm{FSA}]-\mathrm{Li}[\mathrm{FSA}]$.

discussed in this paper. As shown in a previous paper, there are two types of changes in morphology, ribbon type lithiation and flat-plate type lithiation, during the charge process of the Si thin flakes. ${ }^{9}$ In this study, operando SEM observations reveal that the lithiation behavior depends on the IL electrolyte species. In the 83.3-16.7 $\mathrm{mol} \%$ [ $\left.\mathrm{C}_{2} \mathrm{mim}\right][\mathrm{FSA}]-\mathrm{Li}[\mathrm{TFSA}]$ electrolyte, many wrinkles appeared after the lithiation (ribbon type lithiation, Fig. 7a). On the other hand, when 83.3-16.7 mol\% [ $\left.\mathrm{C}_{2} \mathrm{mim}\right][\mathrm{FSA}]-\mathrm{Li}[\mathrm{FSA}]$ was used as the electrolyte, and even though the Si flakes were temporarily bent during the lithiation process, they eventually expanded in the two-dimensional direction with almost no wrinkles after the process (flat-plate type lithiation, Fig. 7b). Considering these new findings obtained from the ex situ XPS and the operando SEM observation, when the major components in the SEI layer are good $\mathrm{Li}$ ion conductors with a sufficient shear modulus (e.g., $\mathrm{LiF}$ and $\mathrm{Li}_{3} \mathrm{~N}$ ), that is, $\left[\mathrm{C}_{2}\right.$ mim] $[\mathrm{FSA}]-\mathrm{Li}[\mathrm{FSA}] \mathrm{IL}$ is used as an electrolyte, the change in morphology tends to be controlled by the flat-plate type lithiation. This means that the lithiation process uniformly proceeds during the charge process due to the SEI layer containing more $\mathrm{LiF}$ and $\mathrm{Li}_{3} \mathrm{~N}$ components. This is the reason why the Si thin flake composite anode LIB cell with $\left[\mathrm{C}_{2} \mathrm{mim}\right][\mathrm{FSA}]-\mathrm{Li}[\mathrm{FSA}]$ shows an interesting battery performance. In contrast, the outstanding rate capability obtained with the 50.0-50.0 $\mathrm{mol} \%\left[\mathrm{C}_{2} \mathrm{mim}\right][\mathrm{FSA}]-\mathrm{Li}[\mathrm{FSA}]$ electrolyte is due to the effect of both higher $\mathrm{Li}(\mathrm{I})$ carrier density and higher abundance ratio of $\mathrm{Li}_{3} \mathrm{~N}$, which has a very high $\mathrm{Li}(\mathrm{I})$ conductivity $\left(1 \times 10^{-3} \mathrm{~S} \mathrm{~cm}^{-1}\right.$ at $300 \mathrm{~K},{ }^{35} c f . \mathrm{LiF}: 6 \times 10^{-6} \mathrm{~S} \mathrm{~cm}^{-1}$ at $\left.323 \mathrm{~K}^{36}\right)$, in the SEI layer.

Based on the findings of this study, schematic illustrations of a plausible lithiation mechanism on the Si thin flake in the binary $\left[\mathrm{C}_{2} \mathrm{mim}\right][\mathrm{FSA}]-\mathrm{Li}[\mathrm{TFSA}]$ and $\left[\mathrm{C}_{2} \mathrm{mim}\right][\mathrm{FSA}]-\mathrm{Li}[\mathrm{FSA}] \mathrm{IL}$ electrolytes are depicted in Fig. 8. Blue, pink, purple, green, and orange parts indicate the chemical components of LiF, $\mathrm{Li}_{3} \mathrm{~N}, \mathrm{Li}_{2} \mathrm{SO}_{4}, \mathrm{Li}_{2} \mathrm{~S}$, and sulfone contained in the SEI layer, respectively. In cases where the $\left[\mathrm{C}_{2} \mathrm{mim}\right][\mathrm{FSA}]-\mathrm{Li}[\mathrm{TFSA}]$ electrolyte is used, favorable $\mathrm{Li}(\mathrm{I})$ conductive components, LiF and $\mathrm{Li}_{3} \mathrm{~N}$, do not distribute uniformly in the SEI layer as they are not the major components. This caused an inhomogeneous lithiation of the Si thin flakes and thus, the morphology is a ribbon- 
(a)

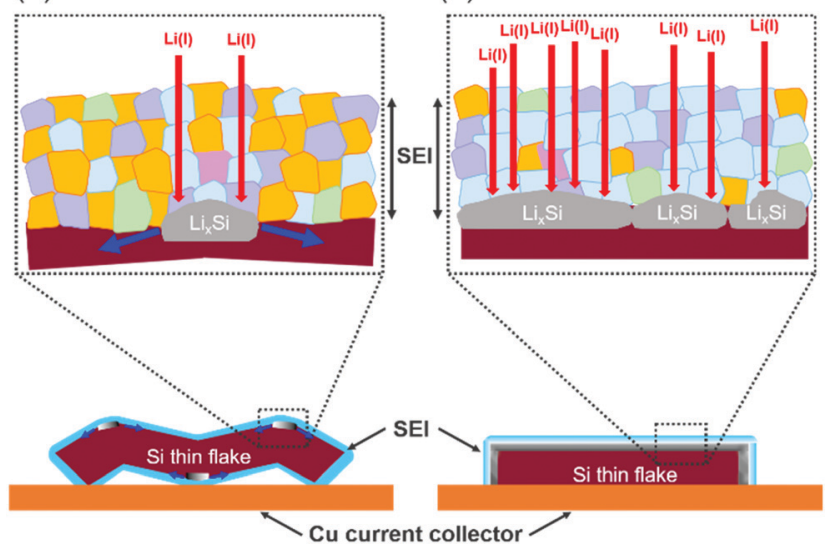

Fig. 8 Schematic illustrations of the SEl film formed during the charge process of the binder-free Si anode in (a) 83.3-16.7 mol\% [C C $_{2}$ mim] [FSA]-Li[TFSA] and (b) 83.3-16.7 mol\% [C $\left.\mathrm{C}_{2} \mathrm{mim}\right][\mathrm{FSA}]-\mathrm{Li}[\mathrm{FSA}]$ or $50.0-50.0 \mathrm{~mol} \%$ [C $\left.\mathrm{C}_{2} \mathrm{mim}\right][\mathrm{FSA}]-$ Li[FSA]. The parts painted in each color show different components: (blue) LiF; (pink) $\mathrm{Li}_{3} \mathrm{~N}$; (purple) $\mathrm{Li}_{2} \mathrm{SO}_{4}$; (green) $\mathrm{Li}_{2} \mathrm{~S}$; and (orange) sulfone.

like structure (Fig. 8a). Meanwhile, in the [ $\left.\mathrm{C}_{2} \mathrm{mim}\right][\mathrm{FSA}]-\mathrm{Li}[\mathrm{FSA}]$ electrolyte, since the major components are $\mathrm{LiF}$ and $\mathrm{Li}_{3} \mathrm{~N}, \mathrm{Li}(\mathrm{I})$ can uniformly diffuse via those components to the Si flakes and the lithiation reaction proceeds homogeneously. Consequently, the $\mathrm{Si}$ thin flakes isotropically expand during the charge process (Fig. 8b). It should be remembered that these components also have a desirable shear which can contribute to the improvement of the SEI layer strength.

\section{Conclusions}

The effects of the Li salt species, Li[FSA] and Li[TFSA], and their molar fraction in the binary $\left[\mathrm{C}_{2} \mathrm{mim}\right][\mathrm{FSA}]-\mathrm{Li}[\mathrm{FSA}]$ and $\left[\mathrm{C}_{2} \mathrm{mim}\right][\mathrm{FSA}]-\mathrm{Li}[\mathrm{TFSA}]$ IL electrolytes on the $\mathrm{Si}$ thin flake composite anode were investigated by evaluating the battery performance and analyzing the battery reactions. Among the LIB full cells prepared in this study, the best combination of the $\mathrm{Si}$ thin flake composite anode and the binary 50.0-50.0 mol\% $\left[\mathrm{C}_{2} \mathrm{mim}\right][\mathrm{FSA}]-\mathrm{Li}[\mathrm{FSA}]$ IL electrolyte, achieved a discharge capacity of $1100 \mathrm{~mA} \mathrm{~h} \mathrm{~g}{ }^{-1}$ even after 500 cycles at 3C rate. The combinatorial analysis by ex situ XPS analysis and operando SEM observation revealed the reasons behind the Si thin flake composite anode LIB full cells with $\left[\mathrm{C}_{2} \mathrm{mim}\right][\mathrm{FSA}]-\mathrm{Li}[\mathrm{FSA}]$ showing outstanding battery performances, such as good cyclability and high rate capability. The differences of morphological variations in Si thin flakes during the charge process are attributable to the chemical species contained in the SEI layer and their abundance ratios. The approach reported in this paper can effectively enhance the battery performance through the combination of active materials and IL electrolytes and is a novel LIB design methodology.

\section{Conflicts of interest}

There are no conflicts to declare.

\section{Acknowledgements}

This research was partially supported by the Advanced Low Carbon Technology Research and Development Program (ALCA) for Specially Promoted Research for Innovative Next Generation Batteries (SPRING) (grant number JPMJAL1301), the Japan Science and Technology Agency (JST) and the JST-MIRAI program (grant number JPMJMI17E9). The silicon thin flakes ( $\mathrm{Si}$ LeafPowder ${ }^{\circledR}$ ) were provided by OIKE \& Co., Ltd (Kyoto, Japan).

\section{References}

1 R. Schmuch, R. Wagner, G. Hörpel, T. Placke and M. Winter, Nat. Energy, 2018, 3, 267-278.

2 M. Armand and J. M. Tarascon, Nature, 2008, 451, 652-657.

3 C. K. Chan, H. Peng, G. Liu, K. McIlwrath, X. F. Zhang, R. A. Huggins and Y. Cui, Nat. Nanotechnol., 2008, 3, 31-35.

4 M. Ge, J. Rong, X. Fang and C. Zhou, Nano Lett., 2012, 12, 2318-2323.

5 H. Wu, G. Chan, J. W. Choi, I. Ryu, Y. Yao, M. T. McDowell, S. W. Lee, A. Jackson, Y. Yang, L. Hu and Y. Cui, Nat. Nanotechnol., 2012, 7, 310-315.

6 J. Graetz, C. C. Ahn, R. Yazami and B. Fultz, Electrochem. Solid-State Lett., 2003, 6, A194.

7 M. Saito, T. Yamada, C. Yodoya, A. Kamei, M. Hirota, T. Takenaka, A. Tasaka and M. Inaba, Solid State Ionics, 2012, 225, 506-509.

8 T. Okubo, M. Saito, C. Yodoya, A. Kamei, M. Hirota, T. Takenaka, T. Okumura, A. Tasaka and M. Inaba, Solid State Ionics, 2014, 262, 39-42.

9 C.-Y. Chen, T. Sano, T. Tsuda, K. Ui, Y. Oshima, M. Yamagata, M. Ishikawa, M. Haruta, T. Doi, M. Inaba and S. Kuwabata, Sci. Rep., 2016, 6, 36153.

10 M. Haruta, R. Hioki, T. Moriyasu, A. Tomita, T. Takenaka, T. Doi and M. Inaba, Electrochim. Acta, 2018, 267, 94-101.

11 D. R. MacFarlane, N. Tachikawa, M. Forsyth, J. M. Pringle, P. C. Howlett, G. D. Elliott, J. H. Davis, M. Watanabe, P. Simon and C. A. Angell, Energy Environ. Sci., 2014, 7, 232-250.

12 M. Armand, F. Endres, D. R. MacFarlane, H. Ohno and B. Scrosati, Nat. Mater., 2009, 8, 621-629.

13 T. Sugimoto, Y. Atsumi, M. Kono, M. Kikuta, E. Ishiko, M. Yamagata and M. Ishikawa, J. Power Sources, 2010, 195, 6153-6156.

14 B. Philippe, R. Dedryvere, M. Gorgoi, H. Rensmo, D. Gonbeau and K. Edstrom, J. Am. Chem. Soc., 2013, 135, 9829-9842.

15 E. Markevich, G. Salitra, A. Rosenman, Y. Talyosef, D. Aurbach and A. Garsuch, RSC Adv., 2014, 4, 48572-48575.

16 D. Molina Piper, T. Evans, K. Leung, T. Watkins, J. Olson, S. C. Kim, S. S. Han, V. Bhat, K. H. Oh, D. A. Buttry and S. H. Lee, Nat. Commun., 2015, 6, 6230.

17 J. Wang, Y. Yamada, K. Sodeyama, E. Watanabe, K. Takada, Y. Tateyama and A. Yamada, Nat. Energy, 2017, 3, 22-29.

18 Y. Yamada, K. Usui, K. Sodeyama, S. Ko, Y. Tateyama and A. Yamada, Nat. Energy, 2016, 1, 16129. 
19 J. Qian, W. A. Henderson, W. Xu, P. Bhattacharya, M. Engelhard, O. Borodin and J. G. Zhang, Nat. Commun., 2015, 6, 6362.

20 K. Yoshida, M. Nakamura, Y. Kazue, N. Tachikawa, S. Tsuzuki, S. Seki, K. Dokko and M. Watanabe, J. Am. Chem. Soc., 2011, 133, 13121-13129.

21 Y. Yamada, K. Furukawa, K. Sodeyama, K. Kikuchi, M. Yaegashi, Y. Tateyama and A. Yamada, J. Am. Chem. Soc., 2014, 136, 5039-5046.

22 T. Tsuda, K. Hosoya, T. Sano and S. Kuwabata, Electrochim. Acta, 2019, 319, 158-163.

23 Y. Yang, D. Chen, B. Liu and J. Zhao, ACS Appl. Mater. Interfaces, 2015, 7, 7497-7504.

24 T. Tsuda, T. Kanetsuku, T. Sano, Y. Oshima, K. Ui, M. Yamagata, M. Ishikawa and S. Kuwabata, Microscopy, 2015, 64, 159-168.

25 A. F. Armand, Jr., L. A. King, J. A. Levisky and J. S. Wilkes, J. Phys. Chem., 1984, 88, 2609-2614.

26 B. Philippe, R. Dedryvère, M. Gorgoi, H. Rensmo, D. Gonbeau and K. Edström, Chem. Mater., 2013, 25, 394-404.

27 A. Kohandehghan, P. Kalisvaart, K. Cui, M. Kupsta, E. Memarzadeh and D. Mitlin, J. Mater. Chem. A, 2013, 1, 12850.
28 L. Chen, K. Wang, X. Xie and J. Xie, J. Power Sources, 2007, 174, 538-543.

29 G. M. A. Girard, M. Hilder, N. Dupre, D. Guyomard, D. Nucciarone, K. Whitbread, S. Zavorine, M. Moser, M. Forsyth, D. R. MacFarlane and P. C. Howlett, ACS Appl. Mater. Interfaces, 2018, 10, 6719-6729.

30 M. Olschewski, R. Gustus, O. Höfft, A. Lahiri and F. Endres, J. Phys. Chem. C, 2017, 121, 2675-2682.

31 F. Buchner, M. Bozorgchenani, B. Uhl, H. Farkhondeh, J. Bansmann and R. J. Behm, J. Phys. Chem. C, 2015, 119, 16649-16659.

32 S. Uchida, U. Imamura and M. Ishikawa, Electrochemistry, 2018, 86, 29-31.

33 S. Xiong, K. Xie, E. Blomberg, P. Jacobsson and A. Matic, J. Power Sources, 2014, 252, 150-155.

34 T. Tsuda, E. Mochizuki, S. Kishida, K. Iwasaki, K. Tsunashima and S. Kuwabata, PLoS One, 2014, 9, e91193.

35 U. v. Alpen, A. Rabenau and G. H. Talat, Appl. Phys. Lett., 1977, 30, 621-623.

36 C. Li, L. Gu and J. Maier, Adv. Funct. Mater., 2012, 22, 1145-1149. 